\title{
PERSISTENCE AND CHANGE OF AFGHAN-GERMAN ECONOMIC COOPERATION - THE CASE OF THE NEW BAGHLAN SUGAR COMPANY
}

\author{
Hermann Kreutzmann and Stefan Schütte \\ With 5 figures and 4 photos \\ Received 01. July 2009· Accepted 18. November 2009
}

\begin{abstract}
Summary Rebuilding a national economy in a conflict situation poses a host of challenges, and this holds true especially for contemporary Afghanistan. The case of the New Baghlan Sugar Company is taken as a precedent for analysing continuity and change in Afghan-German relations and in an agro-industrial enterprise that was conceived in the 1930s and has survived until today. Today, as in the past, cooperation partners have included the Afghan government and Afghan private entrepreneurs as well as the German government and German private entrepreneurs. Sugar beet production and its processing as a joint-effort to substitute sugar imports in Afghanistan were propagated as a profitable undertaking carried out in the spirit of modernisation. The study shows the constraints from the early days as well as the challenges for the public-private partnership of today. A prominent symbol of Afghan-German cooperation is taken as a case in point for elaborating on the current challenges and constraints. Despite substantial subsidies, the full operation of the factory has not been achieved and sugar beet production remains far below expectations. Barriers to development remain high three years into the project, and the comparative study highlights difficulties along the production chain and discusses the findings in the framework of national and local politics.
\end{abstract}

Zusammenfassung: Der Wiederaufbau einer Volkswirtschaft in Konflikt-Gesellschaften steht vor großen Herausforderungen, und in besonderem Maße gilt dies für das heutige Afghanistan. Das Beispiel der „New Baghlan Sugar Company“ wird zur Erläuterung von Kontinuität und Wandel der afghanisch-deutschen Beziehungen in agro-industriellen Unternehmungen vorgestellt. Die Fabrik wurde in den 1930er Jahren errichtet und existiert bis heute. Diese Kooperation zwischen öffentlichen und privaten Investoren auf beiden Seiten verfolgte damals wie heute ähnliche Ziele. Zuckerrübenanbau und die Herstellung von Weißzucker sollten die afghanischen Importe an Zucker weitgehend substituieren. Damals wie heute wurde ein Ansatz verfolgt, der von modernisierungstheoretischen Überlegungen getragen war. Die Untersuchungsergebnisse belegen die damaligen Probleme und Herausforderungen ebenso, wie sie die grundsätzlichen Einschränkungen, Bedrohungen und kritischen Schwellenwerte heute aufzeigen. Das Symbol afghanisch-deutscher Kooperation dient hier als Fallstudie zur Erhellung der Komplexität der Herausforderungen im Konfliktfeld eines vorgeblichen Wiederaufbaus früherer Strukturen. Trotz einer umfangreichen öffentlichen Förderung und privater Investitionen kann die Produktivität der Zuckerfabrik bislang keinesfalls an frühere Erträge anknüpfen. Entlang der Wertschöpfungskette erweisen sich alle Elemente als problembeladen und kritisch. Die Ergebnisse werden eingebettet in nationale und lokale politische Auseinandersetzungen um Macht und Dominanz, die das Überleben und die persönliche Sicherheit der Beteiligten gefährden.

Keywords: Afghanistan, agro-industries, conflict, development, sugar production, import substitution, public-private partnership

\section{Introduction}

Eight years after the ouster of the Taliban regime, the political and economic reconstruction of Afghanistan continues at a slow pace and is confronted with recurrent backlashes. The Afghan economy had adjusted to war conditions and the transition into civil structures for the provision of basic goods and services to local people has not yet been fully accomplished. For this transition to be successful, the agricultural economy serves as a major foundation. However, rehabilitation in a devastated country and the programmatic structure for the creation of a suitable infrastructure, a secure environment and sustainable livelihoods in a conflict situation are often described as being out of step with agricultural realities in Afghanistan (cf. Christoplos 2007). Interventions into the agricultural economy also shape the 'alternative livelihoods' approach as the major programmatic intervention that directs international efforts to combat the war and illicit economies in Afghanistan (cf. Mansfield and Pain 2005). Rehabilitation and development in the agricultural sector seeking to build an alternative livelihood thus aim for social reforms, 
adapted infrastructural assets and the establishment of modern economic enterprises, often following a neoliberal role model for a globalized world and depending on substantial external support and expertise. This trend is also represented in the Afghanistan National Development Strategy and in particular its component referred to as the "Agriculture and Rural Development Sector Strategy" (GoA 2008). This donor-driven strategy aims at modernisation through the promotion of large scale commercial agriculture with an emphasis on production for markets and represents a shift away from supporting subsistence production (cf. Flaming and Roe 2009). The example of sugar production in Afghanistan with its focus on the creation of market oriented producers represents a case in point for how it is attempted to achieve such commercialisation.

Another important strategic pillar governing economic policy in Afghanistan is the privatisation of state-owned enterprises. This strategy, which aims to attract foreign investment into domestic industries, has been subjected to some scrutiny (PATERSON et al. 2006), arguing that privatisation as a means to increase economic efficiency had not yet shown its desired potential. There are manifold reasons for this - deficiencies in infrastructure, a lack of a legal and regulatory environment and protection for investments resulting in limited investment across the board have been identified as the major drawbacks to economic growth (ibid). Further, the success of privatising formerly state-owned enterprises often depends on a sufficient supply of raw materials produced under liberalised and highly competitive market conditions, which can turn out to be an additional bottleneck.

The reasons for the success or failure of privatisation in Afghanistan may differ between industries, but generally results have been below expectations (ibid). This is specifically true in the case of the "New Baghlan Sugar Company", a public-private partnership (PPP) programme involving the German and Afghan governments as well as private investors from both countries. The New Baghlan Sugar Company is an exemplary case in point highlighting challenges and constraints of a public-private partnership in a conflict setting and building on a long-standing relationship in industrial development between the Afghan and German governments. The programme aims to revive industrial sugar production and processing in the country, which was once a relatively successful enterprise. In addition to exemplifying AfghanGerman economic cooperation, it can further serve as an object lesson for the strong challenges re-industrialisation of Afghanistan has to face, and it casts light on the problems affecting PPPs in particular. Accordingly, the aim of this study is to identify and analyse the explicit barriers to re-industrialisation and economic development in Afghanistan's sugar sector, thus contributing to a better understanding of import substitution strategies, PPP programmes and local adaptations. The analysis is based on two visits in 2006 and 2008 including three weeks of empirical fieldwork in Baghlan. The latter took mainly place in September 2008 and builds on open interviews with local farmers and factory workers, as well as participating government actors and private stakeholders in the project. ${ }^{1)}$

\section{Public-Private Partnerships in the develop- ment process}

Public-Private Partnerships involving Government and private actors serve as an important tool for development policy and made it on the agenda of most international donor organisations (cf. Wulf 2003). The promise of PPPs is to provide 'win-win' situations where conflicts of interest can be resolved towards the common good (ibid), or where they are perceived as silver bullet to compensate for state failure in the provision of public goods and services through increased efficiency by involving the private sector, as Peltzer (2007) discusses for the cases of Zambia and Kenya. Generally, PPPs imply that state responsibilities are substituted for by the private sector, and that relations of mutual trust help in creating effective delivery of services, e.g. in public health. Increasingly, PPPs are seen as contributing to combat rural poverty, for instance when private agro-industries create new markets for small farmers and provide incentives for enhanced productivity, as well as providing consultation through agricultural extension workers (ibid).

However, whereas PPPs are by now an established tool in development cooperation, their successes depend on a variety of more intrinsic factors such as quality of project design, management skills and the successful transfer of 'know how' and capacity (cf.

1) Altogether, five sugar beet-farmers were interviewed; in-depth biographical interviews with three factory workers were recorded and one group discussion with 15 participating factory workers was conducted; in addition, interviews with two private Afghan investors were carried out as well as with relevant Government actors (the Deputy Ministers of the Ministry of Agriculture, Irrigation and Livestock (MAIL), the Director of Food Security Department, and the Deputy Director of the General Directorate of Land Management (AMLAK)). Further, the technical and administrative management of the factory served as interview partners. 
SCHRÖDER and VerHEYEN 2007). Critics of the increased excitement around PPPs also point to the fact that private involvements and the pressure on PPPs to be economically successful often lead to cutting down work standards and social security measures (cf. WULF 2003). Economic success thus becomes the major determining factor for the viability of PPP projects (Peltzer 2007).

These factors for success and failure of PPPs need to be looked at when assessing the performance of the New Baghlan Sugar Company. However, the situation in Afghanistan resembles a particular case, where aid money serves as additional incentive for the private sector to engage in reconstruction. PPPs are thereby seen as conducive for the reconstruction effort, as a former World Bank country director maintains: "The combination of abundant, cheap public capital from aid flows and weak implementation capacity following suggest that private-public partnerships will be effective in delivering services to the people of countries emerging from conflict" (McKeCHNIE 2002). Further, the risky and conflict-laden environment and attendant vulnerability of investments in Afghanistan seem to call for PPPs as a suitable model that can avert risks by focusing on combined strengths (cf. KLENNERT 2007). However, the lure of high margins to be made combined with the hope for the establishment of new markets for an investors' product, supported by public development financing, comes with strings attached. These refer to the 'partnership' element in PPPs, where under the circumstances prevailing in Afghanistan the Government appears to be unreliable at best, but also to the multiple insecurities resulting out of the conflict situation. In the following, the challenges attached to the PPP-model are exemplified by focussing on the partnership aiming to revive Afghanistan's sugar sector.

\section{History of sugar production in Afghanistan}

Sugar production in Baghlan is historically closely connected with the much acclaimed notion of Afghan-German friendship. The recent reconstruction process supported by the German Government and a German seed company carries on the feel behind this notion. In the true spirit of modernisation, growth poles were to be established in order to generate spin-off effects for regional developments. Cotton factories (e.g. Spinzar in Kunduz) and the processing of agricultural goods aimed at import substitution. Additional benefits were expected from generating local employment and stimulating market devel- opment (cf. GRÖTZBACH 1972a). The New Baghlan Sugar Company represents a true case in point and is part of a bilateral Afghan-German agreement on modernising Afghanistan, a project that already commenced in 1923 with the establishment of the 'Deutsch-Orientalische Handelsgesellschaft' (for details see BARAKI 1996), created "for the purpose of promoting the import and export trade with the lands of the orient, principally with Afghanistan" (Nicosia 1997, 246). ${ }^{2)}$ In the aftermath of King Amanullah's visit to Berlin in 1928 a sizeable number of German townplanners, engineers, teachers and other professional staffs were hired to support the modernisation process in Afghanistan. ${ }^{3)}$ During the reign of Amir Nadir Shah, bilateral cooperation with European governments was intensified and formalised. Northern Afghanistan was identified as a development region suitable for agro-industrial growth-poles with a promising potential for modern production techniques and processing of cultivated crops. The region also represented an experimental ground for new agro-technical innovations, such as the introduction of sugar beet (Beta vulgaris). The first impulse for industrial sugar production in Afghanistan originates from the formation of the Baghlan Sugar Factory through the Afghan National Bank (Bank-i-Melli) in 1936/37. Dupree $(1973,472)$ states: ,'The Banki-Melli served as a center for capital accumulation, and investments flowed back from the bank to northern Afghanistan and contributed greatly to the creation of almost all pre-World War II industrial development at Pul-i-Khumri, Kunduz, and Kabul." Several authors identified the bank's strategy as a catalyst for the investments of influential Afghan entrepreneurs (GRÖTZBACH 1972a: 69; RHEIN and GHaussy 1966, 65-72). The second important pillar for the creation of a successful project was the

2) Even before the creation of this trade company the first diplomatic mission of an Afghan delegation to Germany in 1921 made the following formal requests to the German Government: "the establishment of permanent diplomatic relations; German permission for Afghan students to come to Germany for education and training; the establishment of German schools in Afghanistan; the sending of German engineers, technicians and teachers to Afghanistan; the purchase by Afghanistan of heavy industrial machinery in Germany, especially for its paper and textile industries; and strong and lasting economic ties between the two countries, particularly through greater German participation in Afghanistan's mining industry and the establishment of German industrial plants in Afghanistan" (Nicosia 1997, 241).

3) Cf. Baraki 1996, Dupree 1973, Fraser-Tytler 1953, Fröhlich 1969, Gregorian 1969, Jäkel 1977, Poullada 1973. 
workforce. Consequently, 600 households of colonisers from different ethnic groups (predominantly Pashtun, Tajik and Uzbek) in the vicinity of the sugar factory were part of the major colonisation scheme in Northern Afghanistan. After the commencement of production they were forced to supply the sugar factory with sugar beets on a regular basis. Initially one third of the irrigated land in Baghlan and Ghori was asked to be devoted to sugar beet cultivation, in the long run a share of just one fifth was established as feasible (GrÖtZBACH 1972a, 69, 155; MiCHEL 1959). Eventually, the sugar plant was established at its current location in 1940 (Fig. 1). The entire process was substantially supported by German engineers, and high quality imported machinery was provided through the Czech Skoda factory ${ }^{4)}$ and other European suppliers including Swiss firms. Even the crop resources cultivated for sugar processing were quite unfamiliar to the region. In Afghanistan, cane sugar is well-known while the imported sugar-beets resembled an innovation to the cultivation pattern in the former province of Qataghan. ${ }^{5)}$ The introduction of this new crop required an adjustment of cultivation techniques, the adaptation of the cultivar to arid sub-tropical conditions and the training of farmers and factory workers. As farmers' interest in sugarbeet cultivation needed to be fostered, the experts heavily relied on the support of the autocratic state and an efficient administration to establish sufficient supply for the productive operation of a sugar factory. ${ }^{6)}$ In the initial phase the idea was to substitute half of Afghanistan's sugar import and stabilise the supply of requirements (GRÖTZBACH 1972a, 155; MOHAMMAD ALI 1946, 27). Aspirations and stakes were high as a contemporary observer stated: "The cultivated land of Baghlan was divided in plots of 12 jaribs each. Each farmer was given one of these plots with a sum of 3,300 Afghanis as loan to purchase the necessary im-

4) After Czechoslovakia was turned into a protectorate by Nazi-Germany in March 1939, industrial plants were not only occupied, but equipment was "Germanized" in a way that still can be observed in the appliances of the Baghlan Sugar Factory. An archival document authenticates and confirms the fact that requisitioned factories in Czechoslovakia were made responsible for the delivery of all equipment for Baghlan (Political Archive of the German Foreign Office, Memo from the German Embassy in Kabul to the Foreign Office, dated March 30, 1960).

5) Qataghan is the historical toponym for the present provinces of Baghlan, Kunduz and Takhar.

6) Cf. GrötZBACh 1972a, 1972b: 381. Newly established settlers were forced to comply with cultivation of certain crops in demand, e.g. sugar beet and cotton. plements. As a result of this encouragement, cultivators from all parts of the country flocked there, and those very lands which were arid and the home of scorpions, snakes, mosquitoes and poisonous spiders, were turned into smiling fields, and have now become the centre of hopes of the whole nation, and supplies, besides cereals and cotton, all the beet requirements of the Sugar Factory. Every one now wishes to have a piece of land in this area because of its fertility and good climate" (Mohammad Ali 1946, 27-28). The quote explains that these industrial complexes were meant to be symbols of modernisation, self-reliance and independence. Until then, all sugar had to be imported. The Afghan Sugar Industry of the 1930s and 1940s performed as an early public-private partnership with external support from Germany.

Further witness to the strong German influence is preserved in the original layout plan of the premises dated from 1942, which depicts the sugar plant and its surroundings of the newly established settlement of 'Industrial Baghlan', and where all nomenclature is given in German (Fig. 2). The map in itself is a unique historic document, as it shows how development understood as a process of modernisation was planned and enacted in the 1940s. The sugar factory and its settlement were conceived as an integrated enterprise, combining sugar beet cultivation and its industrial processing with animal husbandry and dairy production, and providing housing to senior factory staff. A school and health facility was provided and veterinary services established. The plan materialised as planned, although parts of it were revised and dedicated early on to housing for ordinary factory workers. Looking at the actual situation as mapped in 2008, however, the divergence between the planning of modernisation and present-day reality after 30 years of recurrent warfare is obvious (Fig. 3). Population displacement and an influx of refugees into industrial Baghlan changed the settlement structures. Many factory workers and their families abandoned their housing in search of a safer place to live, and people from other war areas in Afghanistan gradually trickled into Baghlan and took over the former worker colonies with their largely destroyed houses. Today, only a few factory workers' families still live in those settlements and there is not much left from industrial Baghlan as planned originally - apart, however, from the factory building itself that survived fifteen years of abandonment surprisingly well.

From 1940 onwards, the sugar factory was in almost constant operation for half a century, before production gradually declined during the Soviet occupation and stopped completely at the beginning of 


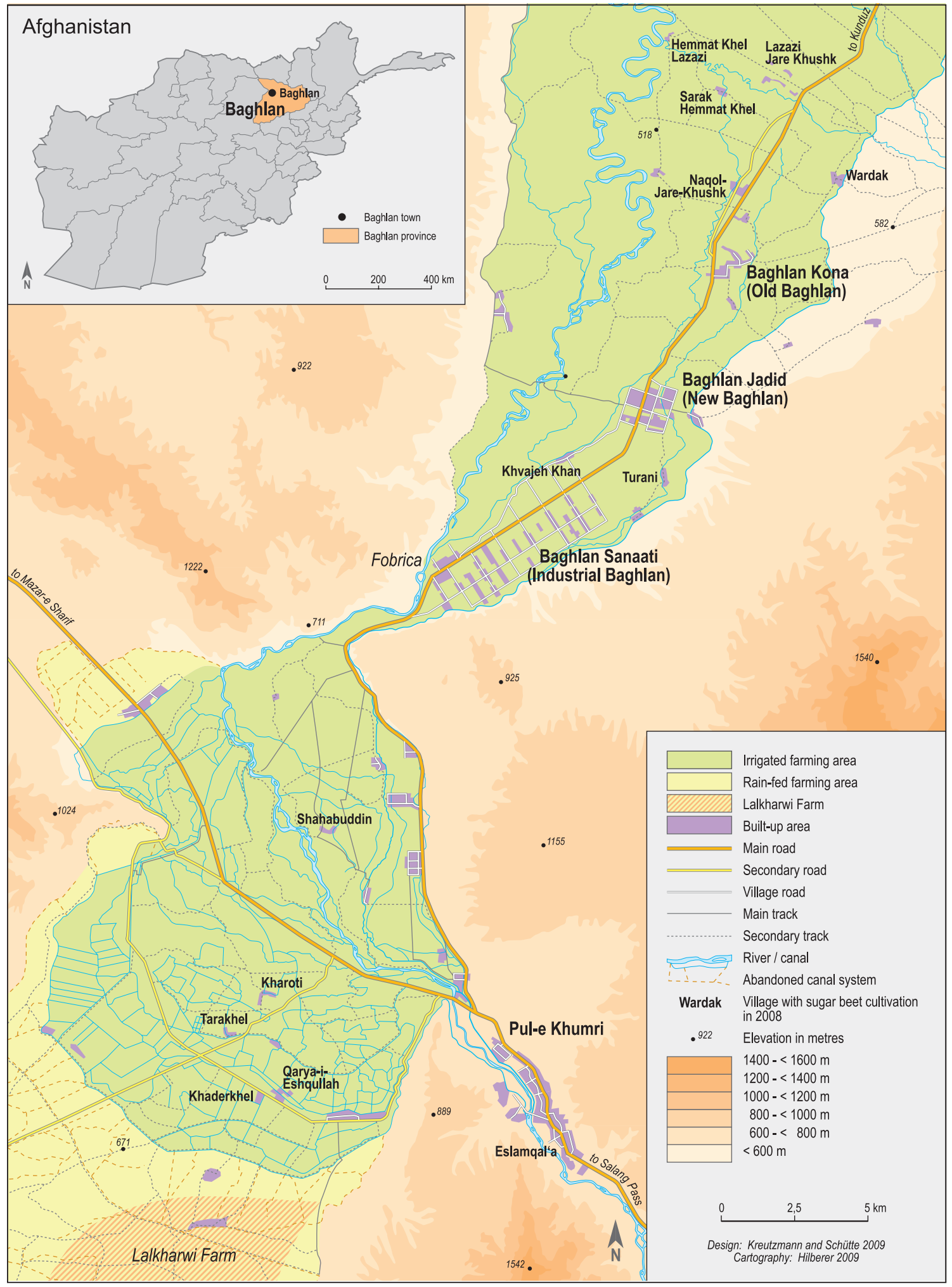

Source: Topography based on Generalny Stab 1:50 000 Topographic Series 1984-1986, sheets J_42_138_1/ J_42_138_2/J_42_138_3/J_42_138_4/ J_42_6_1/J_42_6_2

Fig. 1: Baghlan oasis and its environs - Three urban locations and their agricultural lands. Location of the sugar factory in "Fobrica" and beet-growing villages in 2008 


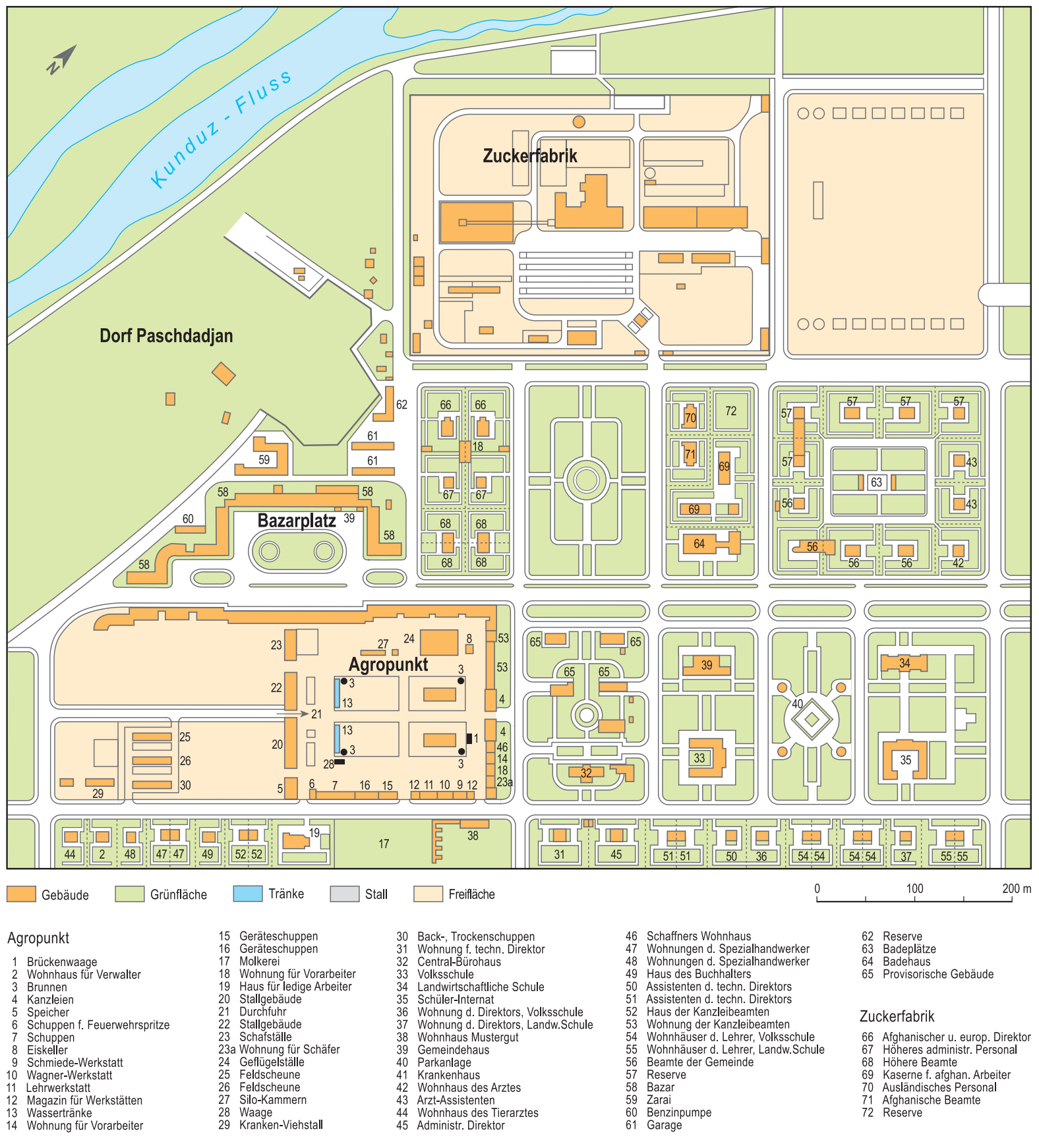

Fig. 2: Layout-plan of Baghlan Sugar Factory in 1942

civil war in the early 1990s (Fig. 4). During Soviet occupation heavy fighting occurred around the factory. As a government enterprise, the factory was protected by Soviet tanks (Photo 1), but came under attack from Mujaheddin forces. Factory workers were caught between the lines, being obliged to resume their duties in the formally operating factory, while at the same time having their lives threatened by anti-government forces. Workers recalled night letters, harassment and violent agitation, and many colleagues being killed by the Mujaheddin simply because they went to work in the factory. In this, the tactics of today's insurgency in Afghanistan strikingly resemble those of the Mujaheddin. 


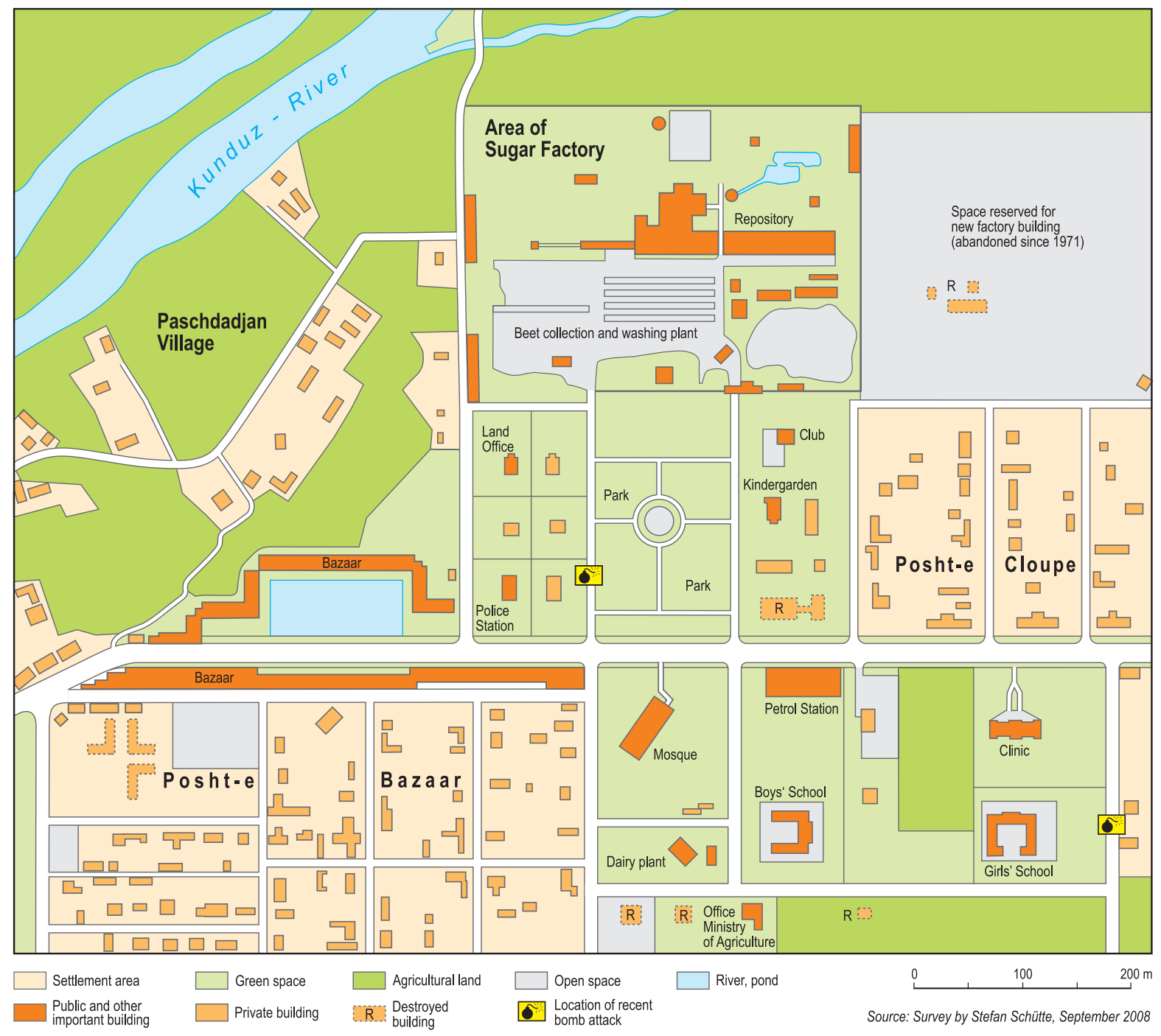

Fig. 3: The New Baghlan Sugar Company and surroundings in 2008

Sugar production in Baghlan has been based on sugar beet right from the beginning, and early agricultural policy was implemented to ensure sufficient supply. The modernisation process in Baghlan was accompanied by a settlement policy that included the distribution of twelve jerib ${ }^{7}$ of fertile irrigated land to farmers in the vicinity of the factory premises. This policy encouraged many farmers to inhabit the new town of industrial Baghlan, also referred to as 'Fobrica'. The pattern of land distribution is still recognisable on maps through the characteristic lattice structure created by a distinctive network of alleys (cf. Fig. 1). Farmers were instructed by autocratic rule to grow sugar beet on one fifth of the distributed land in order

\footnotetext{
7) One jerib equals 0.2 hectare.
}

to supply the factory with sufficient quantities of beet crop and to safeguard the provision of tuber material for the production of sugar, but forced cultivation of beet extended also to previously settled farmers not provided with new agricultural land (cf. GRÖTZBACH 1972a, 155). While overall productivity of beet cultivation was not high compared to international standards, there was a steady supply, guaranteeing regular production of white sugar from Baghlan (Fig. 4). In the initial years of production the harvested sugar beets delivered to the factory amounted to less than 10,000 tons, by the mid-1960s delivery rates reached about 60,000 tons. Despite improved cultivation techniques, supply of mineral fertilizer and improved seeds mainly through a continuing cooperation with companies from the Federal Republic of Germany the 


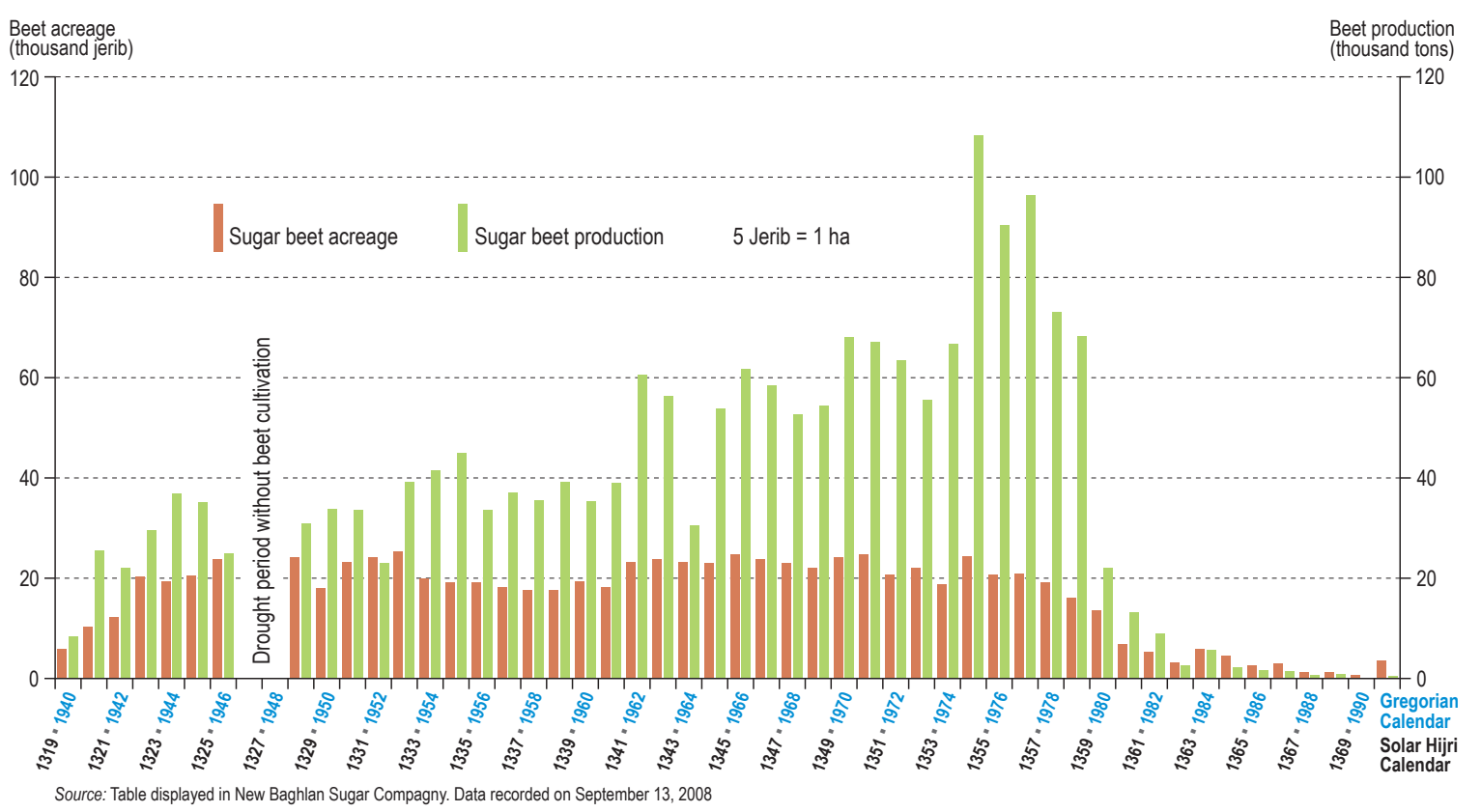

Fig. 4: Half a century of production in the Baghlan Sugar Factory (1940 to 1990)

productivity ${ }^{8)}$ remained low, resembling about a quarter of maximum yields possible under similar climatic conditions elsewhere (GRÖTZBACH 1972a, 155).

Farmers were even encouraged to grow beet beyond the mandatory 20 per cent limit by providing them with incentives such as credit facilities and attractive subsidies for agricultural inputs. Afghanistan was in a position to produce $15 \%$ of its sugar needs in the 1970s, two thirds contributed from sugar beet and almost solely from Baghlan and Ghori.")

The modest success of the only Afghan sugar factory stimulated the formulation of further development plans to increase performance. ${ }^{10)}$ With

8) The productivity of beet cultivation in Baghlan was 9.7 $\mathrm{t} / \mathrm{ha}$ on average, calculated over the 52 years of the factory's production time prior to its reconstruction. The peak was reached in 1976, when productivity arrived at $23.3 \mathrm{t} / \mathrm{ha}$. By contrast, the average productivity of world sugar beet production was $32.7 \mathrm{t} /$ ha in 1986 (cf. Franke 1992).

9) Cf. World Bank 1975, Vol. II, 12-13. The vast majority of Afghan sugar beet has been cultivated in the irrigated oasis of Baghlan which Humlum (1959, 155-156) described as a modern industrial town based on irrigation for the production of sugar and cotton. Between 1955 and 1969 the Afghan agricultural crop statistics show that nation-wide sugar beet cultivation ranged between 3,500 and 4,600 ha in Baghlan and Ghori (RINGER 1972, 315).

10) It should be noted that other constraining factors such as share-cropping have been structuring Afghan farming systems. In the true spirit of modernisation theory and promo- growing demand, the expansion and extension of sugar processing facilities was planned in Herat and Jalalabad. ${ }^{11)}$ In the 1970s, a French company started building a second factory adjacent to the established one, a project which, however, never materialised due to the onset of the Saur Revolution and subsequent violent political transformations. A World Bank report from 1975 assessed great potential in Afghanistan's industrial sugar sector leading to self-sufficiency ${ }^{12)}$, but low productivity and lack of acreage cultivated with sugar beet were identified as major shortcomings to be urgently addressed. The major instrument to do so according to the World Bank advisers would have been an appropriate pricing policy offering incentive prices that would encourage farmers to commit more land to

tion of growth-poles the World Bank report emphasizes industrial production involving irrigation and cash crops. In the mid-1970s sugar beet resembled one of the "modern" enterprises for uplifting the Afghan economy (World Bank 1975, Vol. I, ii, 28, 39, 60).

11) The German Embassy in Kabul was involved in facilitating contacts to potential suppliers of machinery from Czechoslovakia and Poland (Political Archive of the German Foreign Office, Memo from the German Embassy in Kabul to the Foreign Office, dated March 30, 1960).

12) Self-sufficiency in production was projected as an achievable goal if a four-year rotation cycle could be safeguarded requiring a cultivation area of 52,000 ha per factory; cf. World Bank 1975, Vol. II, 13. The same report indicates the likely shortage of irrigation water supply. 


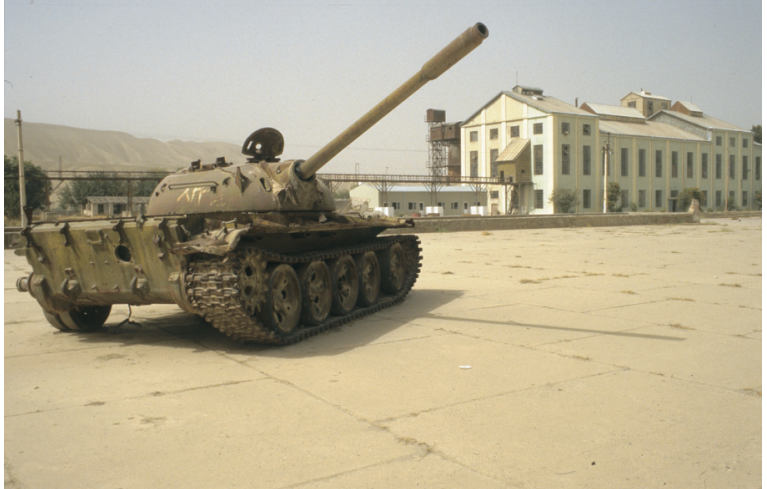

Photo 1: Soviet tank in the premises of New Baghlan Sugar Company (Photo: H. Kreutzmann)

beet cultivation. Both these findings and recommendations became obsolete after the commencement of Soviet occupation. Today, however, the Private-Public Partnership enterprise aiming to sustainably rehabilitate the factory faces similar problems. The difference in present times is that current planning does not foresee providing incentives for farmers to grow beet.

\section{Re-industrialisation in Baghlan: rationale, organisation, and actors}

The endeavour to reopen the Baghlan Sugar Factory serves a number of purposes. First, the demand for sugar in Afghanistan is high and the supply is characterized by meagre domestic production and high shares of imported sugar, making substitution of imports appear a rational approach. Second, the sugar factory project has great symbolic value as it is considered an important step in re-establishing AfghanGerman cooperation in industrial and infrastructural development. Thus, the project aims to demonstrate a continuation of joint projects which originated more than two generations ago. The New Baghlan Sugar Company is a living example of continuity and perseverance of support structures. In addition, the project underlines a development approach which emphasizes a public-private-partnership by activating a set of stakeholders (Fig. 5). Public support is generated from the Afghan Ministry of Agriculture, Irrigation and Livestock (MAIL) while the German side supports the project through training programmes and professional advice facilitated by Capacity Building International (InWEnt). In addition the Food and Agriculture Organisation (FAO) of the United Nations contributes technical expertise which is financed by German attributions. The private sector is represented on the one hand by four Afghan entrepreneurs from an expe- rienced trading family who invested substantial capital into the enterprise. The German private sector is represented by Kleinwanzlebener Saatgut (KWS), a leading company in improved seed production and seeking to re-establish traditional markets for their products in Afghanistan. If successful, the New Baghlan Sugar Company would fulfil the dream of continuity by strengthening Afghan-German economic cooperation. The symbolic value of the endeavour should, therefore, not be underestimated (cf. Photo 2).

The partial privatisation of the Baghlan factory, where the government retains a stake in the PPP and is thereby prone to continued interference and insufficient running of enterprises (PATERSON et al. 2006, 9), resembles a somewhat particular case as the vast majority of Afghan state-owned enterprises have been fully privatised (ibid). This government interference in running the enterprise is of course a defining moment of the PPP, but the private partners both from Afghanistan and Germany perceive this as the most problematic issue in the reconstruction effort. "It is not possible to work with this Government" was a statement made by one of the Afghan investors. This is because an incapacitating government bureaucracy with lack of flexibility apparently brought the project close to failure numerous times during its inception, and there are still a number of conflicting issues defining this particular partnership agreement (cf. Section 5.3). Further, the Afghan investors in the project have no expertise whatsoever in beet-processing, but trusted the early assessments of foreign experts promising a golden future for the venture - a promise which however did not materialise to date. Their engagement to invest into formerly state-owned enterprises however was clearly facilitated by the hope of significant monetary returns, in addition to the more altruistic motive of investing in their home country. ${ }^{13)}$ Paterson et al. however rightly concluded in their assessment of the privatisation process in Afghanistan while explicitly referring to the sugar and cotton industries, that the commercial viability of PPPs would involve significant long-term investments (ibid: 8). However, committing more resources into what is increasingly perceived by the Afghan investors as an endeavour with highly uncertain outcomes was not foreseen.

Thus three years into the project results fare below expectations. The PPP did not get off the ground

13) The private investors also put money into the reconstruction of the Ghuri cement enterprise in Pul-e Khumri. However, there is growing evidence that business increasingly flees Afghanistan and its unstable conditions (cf. MALiKYAR and Goudsouzian 2009). 


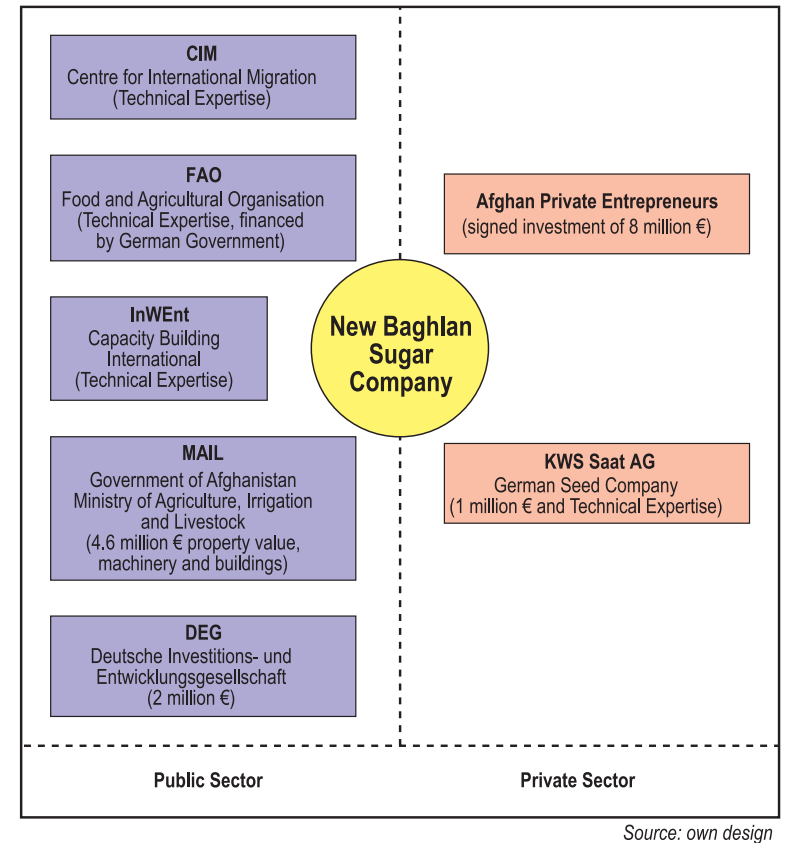

Fig. 5: Actors and stakeholders in New Baghlan Sugar Company project

in spite of a successful technical restoration of the historical sugar plant and its old machinery, and two small production campaigns. The first campaign, after reconstruction in 2006, worked with an input of about 6,000 t of sugar beet gathered from 1,250 jerib under cultivation and produced $113.5 \mathrm{t}$ of white sugar that was sold in local markets. ${ }^{14)}$ The second and, up to now, last campaign occurred in 2008 and could draw on a mere 196.5 jerib cultivated beet, drawn from 96 farming households residing in villages in the vicinity of the factory (cf. Fig. 1). ${ }^{15}$ ) These rather low figures alone indicate that the PPP is stricken with problems forming barriers to development in Afghanistan's sugar sector. These barriers can be clearly identified and are dealt with in turn.

14) As a rule, $100 \mathrm{~kg}$ of sugar beet yield about 12 to $15 \mathrm{~kg}$ of white sugar (cf. Franke 1980, 423). The low output of white sugar is explained by the fact that the factory operated with beets that were infested with a high percentage of dirt and contained only a low percentage of sugar content. This is also because the vegetation period of sugar beet cultivated as a second crop is too short to develop the plants to full maturity.

15) It has to be noted, however, that those production campaigns are a noteworthy successful undertaking in itself, given the antiquity and complexity of available machinery and the state of decay from which these had to be restored. The problems are the high expectations put into the rehabilitation, and the quite naïve hope for immediate economic benefit after reconstruction.

\section{Barriers to development}

The idea of a re-opened sugar factory sounds convincing and in tune with modern development approaches and expectations were high at the outset. Full use of production capacities were projected by the year 2009. Two thousand farmers were supposed to be engaged in the project and acreage of 10,000 ha had been targeted, predicting the creation of 11,000 direct and indirect new jobs. These expected prospects for high profit encouraged Afghan businessmen to commit their high investments in the first place. None of these expectations, however, materialised to date, and not surprisingly the local entrepreneurs now consider withdrawing their funds.

What, then, led to this stark contradiction between expected results at the project's outset and the company's performance after three years? The answer lies in a number of unaddressed bottlenecks and constraints. These refer to the aversion of farmers to dedicate their irrigated land to grow sugar beet for numerous reasons, a lack of capacity permitting to operate the sugar factory without support of foreign experts, and the inability of the company to acquire sufficient landholdings of their own. The fragile security conditions in Baghlan form an additional barrier that puts development efforts under threat.

\subsection{Free markets rule: lack of price incentives leads to aversion of farmers against sugar beet and lack of area under cultivation}

"Sugar is so cheap - why bother producing it here? There is no benefit for farmers, precisely because it is so cheap" (Member of District Assembly in Baghlan on September 11, 2008).

"We farmers are afraid of sugar beet" (Farmer who quit growing beet after the first campaign, September 19, 2008).

The above quotes summarise major challenges for the revitalisation of sugar production in Afghanistan, which to date have only been insufficiently addressed by the envisaged PPP: to provide competitive prices to farmers for their produce so that they are convinced that they cultivate a valuable crop which guarantees a good income, and to counter the aversion of farmers not familiar with the cultivation of a high-maintenance crop like sugar beet. It seems that the term partnership was not conceived of including the farmers.

However, quite contrary to the above quoted recommendation of the World Bank in the 1970s, the 


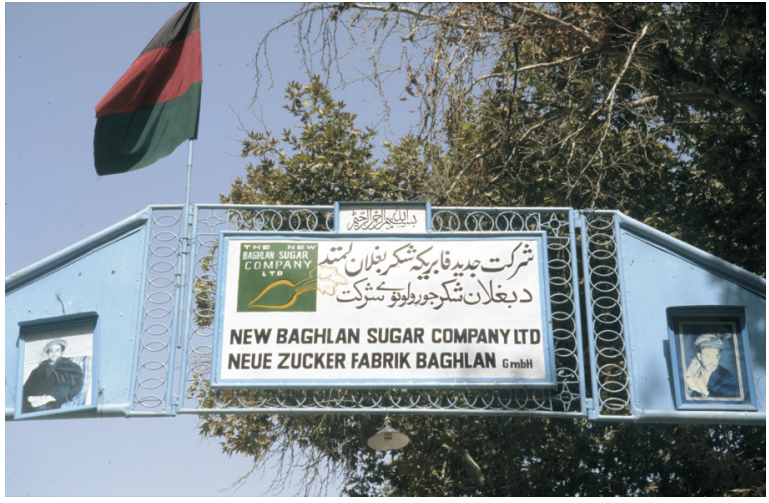

Photo 2: Front gate of the New Baghlan Sugar Company (Photo: H. Kreutzmann)

pricing policy of the sugar factory does not foresee providing incentive prices for farmers to encourage them to devote more acreage for beet cultivation. Thus, farmers quite reasonably do not feel that sugar beet cultivation could be an answer to their production constraints. The dependence on only one buyer of their tuber crops and the fixing of purchase prices by the factory management according to low world market prices has convinced the vast majority of local farmers to refuse to cultivate sugar beet in preference of grain crops, especially wheat (Triticum aestivum) and maize (Zea mays). However, the aversion of farmers stems not only from low prices but also from the fear of crop failure as witnessed by a majority of beet growers over the first production campaign in 2006, when a nematode pest hit the tubers and destroyed more than 80 per cent of the beet crop. Subsequently, sugar beet could only be cultivated as the second crop with a limited vegetation period. The fragility of the beet plant did not help to re-establish trust into the suggested cropping pattern. Paired with what is perceived among farmers as ineffectual management of factory-producer relations, this has led to the sharp decline of acreage under beet, presently leaving the factory with few options to run the factory effectively.

The reasons for farmers' unwillingness to substantially engage in beet cultivation can be summarised as follows:

- Economical: without provision of incentive prices, sugar beet can not compete with grain crops such as wheat and maize. In addition, preparing the field for sugar beet requires comparatively high input investments for mineral fertiliser, high yielding seed material, fungicides and pesticides, seed-bed preparation, irrigation and maintenance, and manual labour force. These inputs are partly provided by the factory, however paid by the farmers when being accounted for after harvesting. With the looming risk of meagre harvests paired with low returns for their crop, this policy bears the risk of farmers falling into debt with the factory.

- Technical: sugar beet is a high maintenance crop, requiring daily care and consistently high work input (cf. Photo 3). The crop is very fragile, demanding daily removal of weeds and very careful watering. These factors are all the more important in that only good quality beet can be delivered and used for production of white sugar. However, many farmers expressed dissatisfaction with the technical support they received from their only customer and cannot live up to the required cultivation standards. There are notable exceptions, however, when skilled farmers engaged in labour intensive care of beet fields were able to fend off the infestation of nematodes and reach superior productivity. These rare cases, nonetheless, also show that high yields are possible which are invariably needed in order to achieve economic benefits. The average productivity is hardly sufficient to make up for the high investments in farm inputs.

- Social: farmers expressed discontent with the modus operandi of beet cultivation and the lack of support received. Many apparently withdrew their acreage for those reasons, complaining about a lack of consultation with local institutions and the reluctance of the factory management to engage in participatory decision-making. In 2006, a large demonstration of farmers in front of the factory gates attempted to draw attention to their needs, but this show of public discontent did not lead to a negotiated and mutually accepted solution.

Today farmers express very clear demands to resolve the situation, the most important of which relates to the provision of subsidies for farm inputs and incentive prices to make beet cultivation attractive. This would also make them effectively a partner in the PPP. After all, they argue, the re-establishment of the factory should be perceived as a long-term commitment to economic development and rural uplift in the region. To be successful, however, this commitment needs the participation of all stakeholders including the farmers.

In summary, it can be stated that all elements of the production and value chain in sugar beet cultivation are problematic. Producers gain next to nothing from cultivating tubers; the sugar factory receives too little crop material to run efficiently; and the investors are not in a position to supply the market with substantial quantities of Baghlan sugar. Dependency on external support has grown. Sugar beet seed has been imported from Germany as well as the exper- 


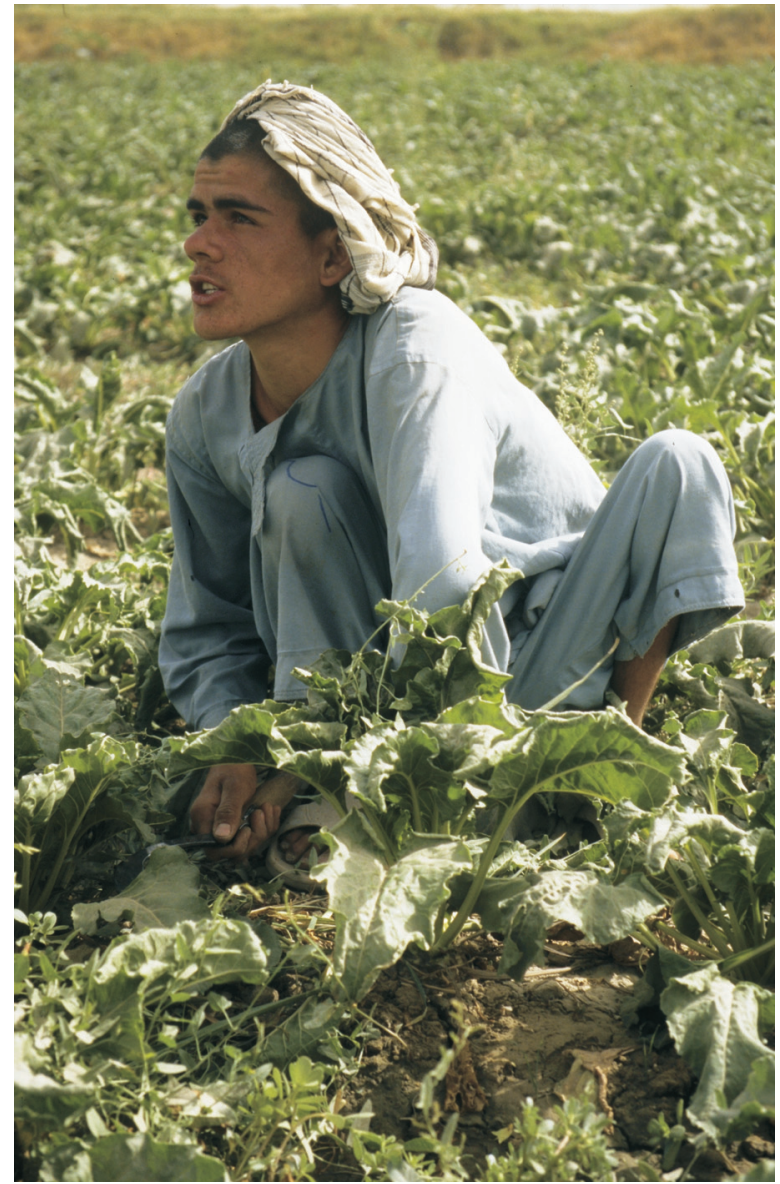

Photo 3: Sugar beet farmer at work - caring for a high maintenance crop (Photo: H. Kreutzmann)

tise to rebuild the factory. To train the technical staff and to support the management has been part of the economic cooperation between Afghanistan and Germany. Therefore the whole enterprise is heavily depending on a continued flow of subsidies. This especially holds true for the technical processes and capacity building for professions that are involved in sugar beet processing.

\subsection{Complexity of sugar production: lack of know-how and capacity building in operat- ing the factory}

While disillusioned farmers and a lack of acreage under beet represent critical constraints for the sugar factory, the sheer fact that the technical restoration of the factory after 15 years of complete standstill has been successful is remarkable in itself. This achievement was possible through the utilisation of foreign expertise and continues to be fully dependent on this external technical support, essentially provided by a single dedicated German sugar engineer. Thus, in order to be sustainable, capacity building of local technicians and factory workers must rank high in terms of priorities. This is especially true as beet-sugar production is a complex process requiring expertise at multiple levels. The sugar beet as a raw product has to pass through no less than 36 technically differentiated stations in the factory to be transformed and processed into refined white sugar, with maintenance and expert supervision of each of these stations being critical to the overall production cycle (cf. Photo 4). Lacking expertise could easily lead to production failure, so that the training of various "station experts" is important for the enterprise as a whole.

However, within the factory premises it is obvious that such continuity has not been achieved. Thus, one of the major pre-condition for the success of a PPP the transfer of capacity and know how - remains unaddressed. In September 2008 the factory employed 49 permanent staff, but during production campaigns up to 300 daily workers are needed. Intermediate maintenance work often needs larger numbers of workers as well, so that employment potential of the factory could be high if sufficient raw material is being produced that can sustain longer production campaigns. Trained and experienced professional staff members have been reactivated despite they had reached pensionable age already. One of the hopeful signs for continuity has been the creation of a few father-and-son teams in which the senior experts give training on the job to their junior apprentices. Some of these teams are presently working in the factory, but at the same time trained personnel is - often forcefully - leaving the factory and taking the institutional knowledge with them. Thus, investments of time and effort in capacity building on the part of the technical management are for various, but often financial reasons sometimes counteracted upon by the factory's administration. While two educated engineering personnel had been successfully trained over a long period and their services secured for the time being and a few stationexperts effectively established, ordinary factory workers complain about working conditions. Especially the reactivated experienced senior workers compare the present situation with the 1970s, when the conditions of employment as government workers were perceived as very favourable. Today, however, the profit-oriented reconstruction led to a cut-back of most basic social security benefits. As one employee put it: "Privatisation of the factory is being carried on the shoulders of factory workers" while at the same time it was acknowledged that without private investments a reopening of the enter- 
prise and thus working in his new old job would have been impossible. Still, a certain sense of discontent is perceptible among ordinary workers. Ensuring ways to increase job satisfaction and to implant a concise programme of capacity building that makes foreign expertise redundant in the long run are pressing tasks at hand in order to direct the factory into a sustainable future where it could act as a major employer in the region. However, given that current stakeholders are facing lack of returns on their investments, the logic of economic profit defining the PPP might even lead to the dismissal of factory staff.

\subsection{Land tenure contested: securing sufficient acreage for beet cultivation}

Insufficient availability of farmland under beet cultivation remains a major threat to further development of the sugar enterprise. While the factory administration has not yet really looked into ways of encouraging local farmers to grow sugar beet, it has sought other ways to expand on available land area. This brings the Afghan government as an important, but apparently very unreliable partner to the publicprivate partnership into greater focus. The factory is trying to lease government farmland to sustain beet production under its own supervision, thus weakening the dependence on private cultivators. This, however, proved to be not as easy as it initially might have appeared, as suddenly the factory is confronted with some of the multifarious land problems the country has to face vis-à-vis a general inability of the government to act against those problems (cf. McEwEN and WhiтTY 2006; WILY 2003).

The farmland in question, located about $40 \mathrm{~km}$ to the Southwest of the factory (cf. Fig. 1), has been established under the reign of President Daud Khan covering an area of about 2,000ha. Out of these 460 ha is flat terrain that could potentially be used for beet cultivation. This would put the factory in the position to control a sizeable share of production and to engage in larger style sugar beet-based agriculture. Consequently it would enable economies of scales by productively using the factory's heavy agricultural machinery that presently is left idle without use at the premises. However, a lease agreement has not been signed, as the Afghan Government is currently not in a position to decree anything that affects agricultural production in Baghlan. The farmland appears to be under the control of a local strongman in an official position who refused to comply with orders from the centre. Even a presidential decree demanding the im-

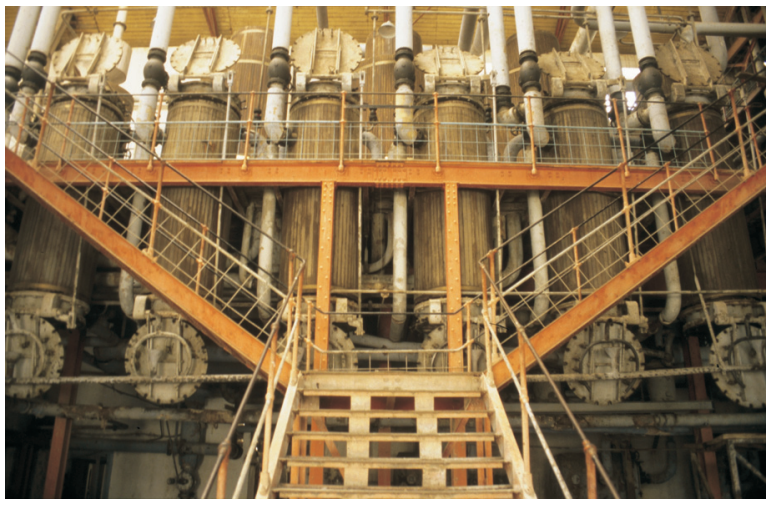

Photo 4: Inside the factory - original devices from the 1940s still in operation (Photo: H. Kreutzmann)

mediate handover of the farmland issued by Hamid Karzai in August 2007 did not change the situation, exemplifying the weakness of the central government when confronted with powerful local leaders who control assets and resources. Further aggravating the situation is the fact that the farmland is put to a significant part under rain-fed cultivation of grain crops, utilised by local farmers from different ethnic groups. Portion of this cultivated land is even under official title deed illegally issued by local courts during the civil war period in which Baghlan faced heavy fighting and changing rulers and control structures. ${ }^{16)} \mathrm{A}$ long bureaucratic process could be due clarifying legal claims to that land and to re-establish government control through implementation of the 'Land Acquisition Law'. Only in October 2008 a four-headed commission has been set up with the task to finally establish the precise modalities under which the farmland can be officially leased out to the sugar factory, though so far without result. This powerlessness of the government is seen as major constraint by the private stakeholders of the PPP, whose chances for a return of their investments are diminishing and who think about acquiring this farmland as one final chance for the economic success of the rehabilitation project. ${ }^{17)}$

16) The case of the farmland under discussion represents but one from many similar examples; according to the Deputy Director of the General Directorate of Land Management (AMLAK) of the MAIL, about 680,000 ha (3.4 million jerib) of government land is illegally occupied by private persons. Vast parts of these lands have been grabbed through force by local power-holders with parcels subsequently being sold and title deeds issued.

17) The private investors even approached the government offering to bribe the local power-holder so that a quick conclusion could be reached, an offer that however has been declined. 
However, even if a lease agreement could be reached at some point in time it is by no means clear that a quick utilisation for beet cultivation can be ensured in the near future. The farmland currently is a stretch of desert located at the southern fringes of the Baghlan oasis (cf. Fig. 1). No irrigation scheme whatsoever has been put into place. There are remnants of never filled canals built in the mid-1970s under the Daud Khan Regime (1973-1978), but putting the area to use for beet cultivation would require a major investment into irrigation systems and soil preparation. Time is running out and funds for further investments are not in sight. Currently it is not apparent who will be ready to handle such investment, which shows that entering a lease agreement would not automatically resolve the land insecurity for beet production. Rather, it asks for further and longer term commitment, and probably for more than a profitoriented approach.

These factors underline the gap between theory and practice of economic reconstruction in conflict Afghanistan. The centre is in no position to decide upon affairs in certain regions. Local leaders do not care about the central government in Kabul. The Afghan nation state is comprised of an administrative environment in which investments are insecure if the entrepreneurs are detached from local power structures. On the other hand, it is exactly this environment that enables local strongmen to generate wealth and to increase their power. The rural population depends for their livelihood security to a higher degree on local actors than on the central government which is powerless when it comes to local decision-making.

\subsection{Security: development efforts under com- batants' threat}

While the problems of land insecurity and lack of capacity pose difficult technical constraints, the deteriorating security environment in Baghlan poses an additional barrier to development in Afghanistan's sugar sector, and hampers the stabilisation of production. Many incidents took place right in Industrial Baghlan, the worst being when the front gate of the New Baghlan Sugar Company featured as the site of a deadly suicide attack directed towards members of Parliament and representatives of the MAIL in November 2007. Infiltration of insurgents into the factory and threats directed towards factory workers and cultivators of sugar beet are another detrimental factor challenging the success of the New Baghlan Sugar Company, while abduction threats against for- eign personnel are not conducive to attracting more foreign experts to support the enterprise in future. The deteriorating security environment further increases the cost of production and poses a major constraint for fostering continuity and sustainability. The central government and the regional administration are, however, in no position to guarantee the security of employees, managers and producers.

Not only is the enterprise a potential target for insurgents, but also the Afghan businessmen holding a major share of the enterprise have to travel under close protection. Organised crime poses specific threats to business in Afghanistan, and it appears that many investors have fled Afghanistan because of a dramatic increase in crime and abductions targeted against businessmen in recent times. This threat paired with the above-mentioned factors might lead the private investors to extract their funds from the enterprise. The German seed company, as the other private player, will be committed to their partnership with the German Government, although economic realities do not correspond to calculations made at the outset.

\section{Conclusions: Development with barriers}

The present failure of the public-private partnership enterprise to reach its central goal of facilitating sustainable economic development in Baghlan can be attributed to the manifold barriers identified above. The question remains whether the for-profit approach to industrial development and import substitution implicit in the PPP approach is the appropriate way to revive Afghanistan's sugar sector? It seems obvious that the specific and fragile situation in Afghanistan coupled with the weak state not being able to support any kind of development requires a different strategy. While the approach taken by the PPP is indeed a rational and convincing one - substituting expensive imports of a much demanded good and thereby creating new economic activity as well as new job opportunities - the sharp focus on quick profit for private shareholders appears quite opposed to the development goals of economic growth and job generation in a rather volatile and insecure area of Afghanistan.

It is worthwhile to reflect on the factors for success and failure of PPPs. It appears that the project already failed because it established an inclusive administrative management whose actions appear to alienate workers and farmers alike and that hinders the transfer of capacity and know-how. The lack of 
economic success of the factory invariably led to what critics of PPPs allege, namely cutting down work standards and social security measures for workers. This does not help in establishing a trained and dedicated workforce that eventually must be enabled to operate the factory as a viable unit. Also, the stated project aim of contributing to rural development in the region was not addressed, as the establishment of a new market for sugar beet did not provide the incentive for farmers to grow the new crop as prices provided by the factory are simply not competitive. Similarly, the quality of rural extension provided by the PPP was harshly criticised by farmers. These constraints culminate in the problem of the Afghan Government being a weak and unreliable partner to the project.

It seems obvious that after complete abundance for 15 years, the re-vitalisation of sugar production in Baghlan needs long term commitment and, at least initially, heavy and committed subsidising and a strong focus on capacity building in order to gradually evolve into a productive enterprise. This also means that farmers would have to be offered incentive prices to encourage them to take on production - without their active contribution the project is doomed to fail in the long run.

Afghan-German cooperation in the sugar sector is thus afflicted by a multiplicity of problems. These problems evidently arise out of lack of coordination between shareholders. While it is true that the Afghan Government is a seemingly unsupportive partner, the general absence of a steering committee that is able to direct the project through its pitfalls hampers and unnecessarily prolongs decision-making processes. Looking at the experience from three years, it seems that while the symbolic value of the project is being upheld, its future success can be only established through major amendments and shifts in strategy. It seems that the PPP approach for reconstruction of Afghanistan's sugar sector is indeed 'out of step' with agricultural realities in the country that so far resist large scale commercialisation of sugar beet. If it is to facilitate sustainable development in the region, the sugar-based venture needs to be supported and operated as a development project, at least initially. As a solely economic undertaking based on the prospect of immediate profits, it is bound to fail. Two scenarios are conceivable at this point: Either the private investors will withdraw and the project will be given up completely, which seems not unlikely, or the approach will be reversed and the project supported as development aid, which will not look for quick profits.
Consequently, the idea to re-establish the Baghlan sugar factory as a symbol of continuity, persistence and future aspirations in the context of a conflict-ridden Afghanistan has been confronted with a wide spectrum of significant challenges. At present, the contribution to local employment and to the commodity market is far from satisfactory. The New Baghlan Sugar Company features as a case in point for the constraints and contra-productive forces that aim at destabilising the meagre growth in agriculture and industrial processing. Further improvements on the long path of development might be achieved by a bottom-up approach that incorporates all local stakeholders including local farmers and factory workers in an effort of participatory decision-making.

\section{Acknowledgements}

We are grateful to the people who have been instrumental in re-building the "New Baghlan Sugar Company" and supported our fieldwork, namely Burkhard Reiser and Dr. Karim Wasiri. Fieldwork in Baghlan was supported by the Deutsche Forschungsgemeinschaft (DFG) through a travel grant in 2006 and with generous sponsorship for the on-going project "Menschliche Sicherheit und Entwicklung in Afghanistan oder welches Umfeld braucht Entwicklung? Regionale Analysen zu Entwicklungschancen in den Provinzen Badakhshan, Baghlan, Kunduz und Takhar" since 2008. In addition we acknowledge the advice and logistical support of Royce Wiles from the Afghanistan Research and Evaluation Unit (AREU).

\section{References}

BAraki, M. (1996): Die Beziehungen zwischen Afghanistan und der Bundesrepublik Deutschland 1945-1978. Europäische Hochschulschriften Reihe 31, Politikwissenschaft 299. Frankfurt a.M.

Christoplos, I. (2007): Narratives of rehabilitation in Afghan agricultural interventions. In: PAIN, A. and SuTTON, J. (eds.): Reconstructing agriculture in Afghanistan. Bourton on Dunsmore, 165-188.

Dupree L. (1973): Afghanistan. Princeton.

Flaming, L. and Roe, A. (2009): Opportunities for pro-poor agricultural growth. Afghanistan Research and Evaluation Unit. Kabul.

Fraser-Tytler, W. K. (1953): Afghanistan. A study of political developments in Central and Southern Asia. London. 
Franke, G. (ed.) (1980): Nutzpflanzen der Tropen und Subtropen 1. Leipzig.

Franke, W. (1992): Nutzpflanzenkunde. Stuttgart, New York.

FröHLich, D. (1969): Nationalismus und Nationalstaat in Entwicklungsländern. Probleme der Integration ethnischer Gruppen in Afghanistan. Afghanische Studien 3. Meisenheim am Glan.

GOA (GOVERNMENT OF AFGHANISTAN) (2008): Agriculture and Rural Development Sector Strategy in the ANDS. Kabul.

Gregorian, V. (1969): The emergence of modern Afghanistan. Politics of reform and modernization, 1880-1946. Stanford.

GrötZBACH, E. (1972a): Kulturgeographischer Wandel in Nordost-Afghanistan seit dem 19. Jahrhundert. Afghanische Studien 4. Meisenheim am Glan.

- (1972b): Staatliche Agrarpolitik und Bodennutzungsgefüge in Nordost-Afghanistan. In: Tagungsbericht und wissenschaftliche Abhandlungen. Deutscher Geographentag Erlangen-Nürnberg 1971. Wiesbaden, 380389.

Humlum, J. (1959): La géographie de l'Afghanistan. Etude d'un pays aride. Publications de l'Institut de Géographie de l'Université d'Aarhus 10. Copenhague.

JäKEL, K. (1977): Reform und Reaktion in Afghanistan. Notizen zu Aufstieg und Fall Amanullahs. In: Mardom Nameh. Hefte zur Geschichte und Gesellschaft des Mittleren Orients 3, 24-57.

KLEnNert, K. (2007): Reconstruction of the sugar sector in Afghanistan. In: Entwicklung und Ländlicher Raum 2, 29-31.

Malikyar, H. and Goudsouzian, T. (2009): Business flees Afghan instability.

http://english.aljazeera.net/fcus/2009/11/200911117 2339356853.html (18. Nov. 2009)

Mansfield, D. and Pain, A. (2005): Alternative livelihoods. Substance or slogan? Kabul: AREU Briefing Paper.

McEwen, A. and Whiтty, B. (2006): Water management, livestock and the opium economy: land tenure. Kabul: AREU Briefing Paper.

McKechnie, A. J. (2002): Humanitarian assistance, teconstruction \& development in Afghanistan: a practitioner's view. International Conference on Post-Conflict Reconstruction, November 11-13, Hiroshima.

Michel, A. A. (1959): The Kabul, Kunduz and Helmand Valleys and the national economy of Afghanistan. National Academy of Sciences, Foreign Field research Program 5. Washington DC.

Mohammad Ali (1946): Commercial Afghanistan. Delhi.

NicosiA, F. R. (1997): ‘Drang Nach Osten’ Continued? Germany and Afghanistan during the Weimar Republic. In: Journal of Contemporary History 32 (2), 235-257.
Olesen, A. (1988): Afghanistan: The development of the modern state. In: Ferdinand, K. and Mozaffari, M. (eds.): Islam, state and society. London, 155-169.

Paterson, A.; Blewett, J. and Asif Karimi (2006): Putting the cart before the horse? Privatisation and economic reform in Afghanistan. Kabul: AREU Briefing Paper.

Political Archive of the German Foreign Office (Politisches Archiv Auswärtiges Amt) 1960: Bestand 12, Band 919: Memo from the German Embassy in Kabul to the Foreign Office, dated March 30, 1960: Afghanische Entwicklungsvorhaben; Errichtung von Zuckerfabriken, 416-82.02/3, Ber. Nr. 291/60.

PoulladA, L. B. (1973): Reform and Rebellion in Afghanistan, 1919-1929. King Amanullah's failure to modernize a tribal society. Ithaca, London.

Peltzer, R. (2007): Afrika: Privat-öffentliche Kooperation als Alternative zu Staatsversagen? In: Entwicklung und Ländlicher Raum 2, 4-5.

Rhein, E. and Ghaussy, A. G. (1966): Die wirtschaftliche Entwicklung Afghanistans 1880-1965. Opladen.

Ringer, K. (1972): Die Landwirtschaft. In: Kraus, W. (ed.): Afghanistan. Natur, Geschichte und Kultur, Staat, Gesellschaft und Wirtschaft. Tübingen, 306-327.

Schröder, J. F. and Verheyen, K. (2007): Potenziale und kritische Erfolgsfaktoren bei PPP. In: Entwicklung und Ländlicher Raum 2, 12-13.

WILY, L. A. (2003): Land rights in crisis. Restoring tenure security in Afghanistan. Kabul: Afghanistan Research and Evaluation Unit.

Wulf, A. (2003): Wer gewinnt beim win-win? Zur Kritik der Public Private Partnerships. In: IZ3W- Informationszentrum 3. Welt 271, 14-16.

WORLD BANK (1975): Afghanistan. Opportunities for agricultural and rural development sector report. Vol. I. Washington.

- (1975): Afghanistan. Opportunities for agricultural and rural development sector report. Vol. II. Washington.

\section{Authors}

Prof. Dr. Hermann Kreutzmann Dr. Stefan Schütte

Institute of Geographical Sciences Human Geography

Centre for Develeopment Studies Freie Universität Berlin Malteserstr. 74-100 12249 Berlin

hkreutzm@fu-berlin.de stefan.schuette@fu-berlin.de 